\title{
Analysis of changes in climate and river discharge with focus on seasonal runoff predictability in the Aksu River Basin
}

\author{
Z. W. Kundzewicz $\cdot$ B. Merz $\cdot$ S. Vorogushyn $\cdot$ \\ H. Hartmann · D. Duethmann - M. Wortmann • \\ Sh. Huang $\cdot$ B. Su $\cdot$ T. Jiang $\cdot$ V. Krysanova
}

Received: 15 June 2013/Accepted: 8 February 2014/Published online: 1 March 2014

(C) The Author(s) 2014. This article is published with open access at Springerlink.com

\begin{abstract}
The River Aksu is the principal tributary to the River Tarim, providing about three quarters of its discharge. It originates in Kyrgyzstan and flows into the arid areas of the Xinjiang Uyghur Autonomous Region in China, where an extensive irrigated agriculture has been developed in the river oases. The aim of the present contribution is to review the current trends in temperature, precipitation, and river discharge and links between these variables. The temperature in the region and the river discharge have been rising. Changes were studied using multiple trend analyses with different start and end years. Correlations between daily temperature and discharge are high and statistically significant for two headwater subcatchments of the Aksu for most of the time. However, there are episodes in late summer or beginning of autumn when correlations between temperature and discharge for the Xiehela station are absent. This can only be explained by Glacial Lake Outburst Floods from the Lake
\end{abstract}

Z. W. Kundzewicz · M. Wortmann · Sh. Huang · V. Krysanova Potsdam Institute for Climate Impact Research (PIK), Potsdam, Germany

\section{Z. W. Kundzewicz $(\bowtie)$}

Institute for Agricultural and Forest Environment, Polish

Academy of Sciences, Poznan, Poland

e-mail: kundzewicz@yahoo.com

B. Merz $\cdot$ S. Vorogushyn · D. Duethmann

Helmholtz Centre Potsdam, GFZ German Research Centre for

Geosciences, Potsdam, Germany

H. Hartmann

Slippery Rock University, Slippery Rock, PA, USA

B. Su $\cdot$ T. Jiang

China Meteorological Administration, National Climate Centre,

Beijing, China
Merzbacher that are not routinely monitored. On an annual time scale, changes in summer discharge in the highly glacierized Xiehela subcatchment are dominated by changes in temperature. In contrast, in the subcatchment Shaliguilanke, variations in summer streamflow are more strongly influenced by variations in precipitation. A comparison of links between climatic variables and streamflow at different temporal scales is offered. Perspectives for seasonal forecasting are examined.

Keywords Temperature - Precipitation - Streamflow · Trend detection $\cdot$ River Tarim $\cdot$ River Aksu

\section{Introduction}

The drainage basin of the River Tarim, extending from $35^{\circ} \mathrm{N}$ to $43^{\circ} \mathrm{N}$ and from $74^{\circ} \mathrm{E}$ to $90^{\circ} \mathrm{E}$ and covering an area of $1.02 \times 10^{6} \mathrm{~km}^{2}$, is one of the largest endorheic systems (closed hydrological systems without outflow) worldwide. Most of the basin is located in the Xinjiang Uyghur Autonomous Region of Northwestern China. The climate in the basin is continental and arid to hyper-arid with a large temperature amplitude so that a major part of the basin is covered by the Taklamakan Desert. It is the most remote area from oceans and large water bodies worldwide. The very low mean annual precipitation (around $40 \mathrm{~mm}$ ), displays an annual cycle with a maximum in summer (June to August) and a minimum from November to January (Bothe et al. 2012). The moisture to the Tarim basin is mainly supplied by westerly flows, with the westerly jet location and intensity determining the seasonal variation in the moisture route (Bothe et al. 2012). In some years, the total precipitation in the Taklamakan Desert is equal to zero. Annual precipitation is higher (up to $400 \mathrm{~mm}$ and 
more) in high mountains surrounding the desert, from where snow and glacier melt feed the River Tarim through its tributaries. The total snow and ice-melt contribution to the River Tarim is estimated at about $48 \%$ (taken from Xu et al. 2009a). Dikikh (1993) provides a similar number of $46.7 \%$ but solely for the contribution from glacierized surfaces, which includes primarily glacier melt, but also snowmelt from and precipitation on glacier surface (cf. Zhao et al. 2013). The runoff contribution from glacierized surface in Aksu basin was estimated at $46.3 \%$ (Dikikh 1993). The water of the River Tarim constitutes a major source of water resources in the region (Wu 2012). In the past, the River Tarim reached the Lake Lop Nur, which is now a dry, salt-encrusted lake bed. Now the river empties into the Lake Taitema, about $160 \mathrm{~km}$ upstream of the Lake Lop Nur.

Since water resources in the arid basin of the River Tarim are very scarce, ecosystems and the social systems are vulnerable to adverse changes in river flow. The two basic drivers of change of water availability in the basin are intensive agricultural land use and climate change. For half of the last century, intensive exploitation of water resources in the basin, mainly for irrigated agriculture, has resulted in changes in the temporal and spatial distribution of water availability (cf. Wang et al. 2010). The main agricultural crop in the basin is cotton, but there are also large fruit plantations (grapes, pears, apricots, and nuts). Feike et al. (2014) show that the agricultural land area in the AksuTarim Basin more than doubled 1989-2011. This has led to a plethora of environmental problems, such as discontinuity of river flow and salinization affecting large areas of agricultural soils.

The largest inflow among all the tributaries of the River Tarim is provided by the perennial discharge of the River Aksu - the principal left-hand tributary to the River Tarim, with a total length of $282 \mathrm{~km}$. Although the area of the Aksu River basin $\left(42,000 \mathrm{~km}^{2}\right)$ is only less than $5 \%$ of the area of the entire Tarim River basin, the average annual flow of the River Aksu (203.5 $\left.\mathrm{m}^{2} \mathrm{~s}^{-1}, 1952-2004\right)$ accounts for $70-80 \%$ of the average annual flow of the River Tarim. The River Aksu is a transboundary river, originating in Central Tien Shan in Kyrgyzstan (named Sary-Djaz there) and draining into the Xinjiang Uyghur Autonomous Region of China.

Numerous studies have been performed for analysis of trends in climate variables (in particular, temperature, $T$, and precipitation, $P$ ) and river runoff $(Q)$ in the Tarim basin and its tributaries (cf. Xu et al. 2010, 2011, 2011; Fan et al. 2011; Chen et al. 2009). Based on station and gridded data several researchers converge to an estimate that temperature in the Tarim basin increased by about $0.8^{\circ}-1^{\circ}$ over the period of 50 years until mid 2000s and this change is statistically significant for a vast portion of the catchment (Chen et al. 2007,
2009; Ling et al. 2013; Krysanova et al. 2014), and the largest contribution to this increase comes from the period since 1985 (Chen et al. 2009). On the contrary, Tao et al. (2010) and Ling et al. (2013) found an abrupt change point towards a stronger temperature increase in 1996 in the northern tributaries of Tarim. The majority of studies agree on the slight precipitation increase from the late 1950s to mid 2000s (e.g. Ling et al. 2013). Changes in flow of the River Tarim and its tributaries have already been extensively studied by several researchers, who also tried to link these changes to variability in climate factors and anthropogenic activity. Chen et al. (2009), Xu et al. (2009b), and Ling et al. (2013) studied trends in runoff of several Tarim tributaries and discussed the link between them and changes in temperature and precipitation. $\mathrm{Xu}$ et al. (2009a) additionally explored the link between the runoff volume and snow depth variations. No influence of El-Niño Southern Oscillation (ENSO) on temperature, precipitation and runoff has been found for the Tarim River Basin (Chen et al. 2009). Finally, Tao et al. (2010) discussed the role of anthropogenic water withdrawal on river flow in the Tarim tributaries and found a significant influence on streamflow. In the neighbouring catchments of Eastern Tian Shan, which show a similar pattern in climatic and hydrological change with comparable degree of glacierization, the changes in runoff particularly in the last two decades seem to be strongly driven by glacier degradation ( $\mathrm{Li}$ et al. 2006, 2010).

The trends in river discharge of the River Aksu were analysed by Krysanova et al. (2014) using monthly data for the period 1957-2004 for the three gauge stations Xiehela, Shaliguilanke and Xidaqiao, considering average monthly, average seasonal and average annual values. Upward, statistically significant, annual and seasonal trends were found for all three stations, with a lower level of significance for the Xidaqiao station.

We complement the previous numerous studies of trends in climatic and hydrologic characteristics of the River Tarim and its tributaries by looking at multiple trend analysis in the Aksu catchment with different start and end points of the time series to explore the variability of trends over the past decades. An extensive correlation analysis between temperature, precipitation and river runoff at various time scales and for several time lags is performed with non-parametric techniques. The elasticity of discharge changes with regards to changes in temperature and precipitation is explored in a subsequent step to analyse the potential predictability of discharge changes. Finally, we look at several climate indices and analyse their potential for seasonal runoff forecasting.

\section{Study area and data}

The Upper Aksu River basin (upstream of Aksu City), cf. Fig. 1, can be subdivided into three subcatchments, 
Fig. 1 Map of the Aksu River Basin

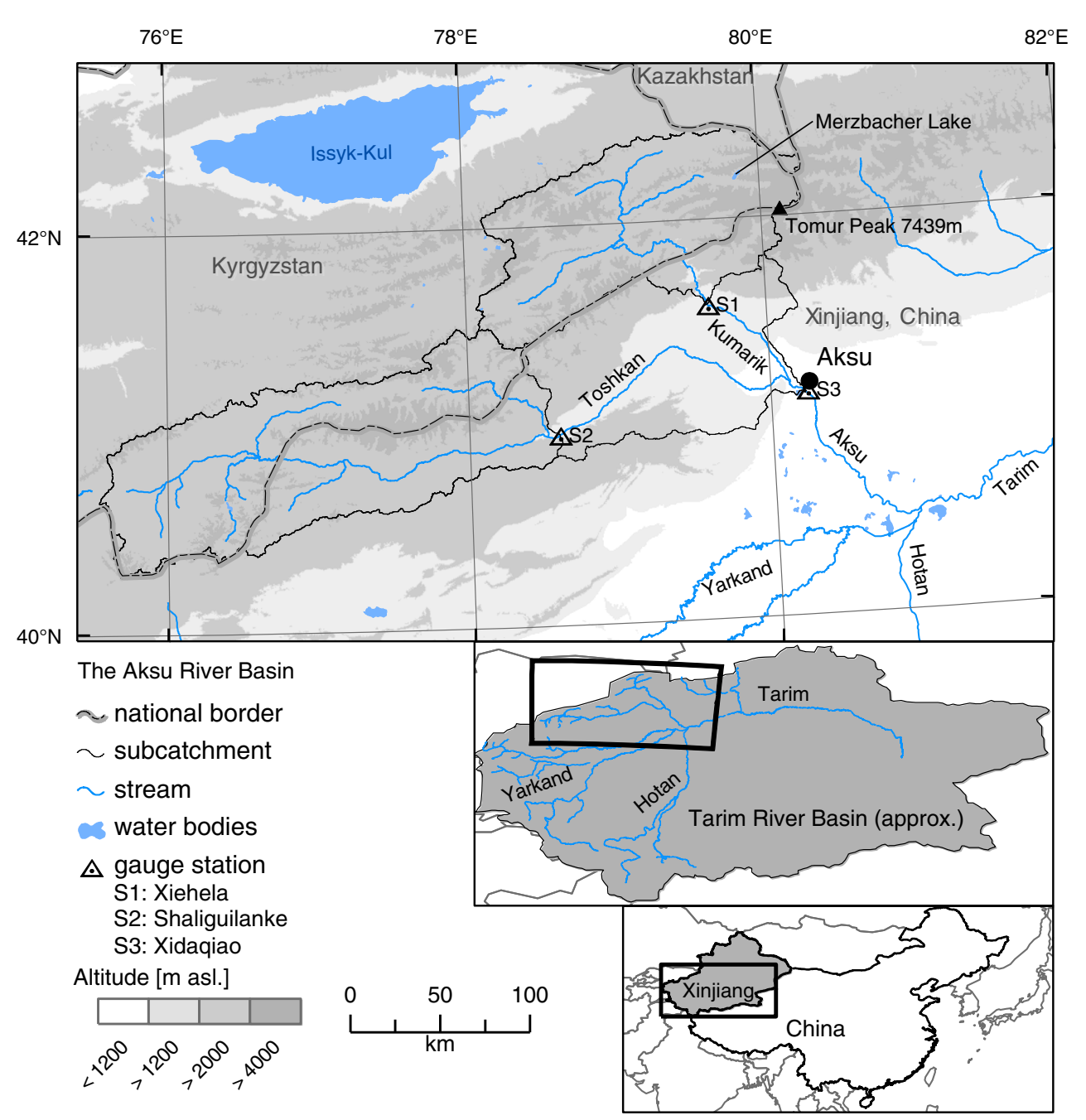

terminated by three hydrological stations: Xiehela, Shaliguilanke, and Xidaqiao. Two gauging stations Xiehela and Shaliguilanke terminate the headwater subcatchments, whereas the Xidaqiao station terminates the lower subcatchment, down to Aksu City. Most of the headwater part is located at altitudes above $2,000 \mathrm{~m}$ with a considerable portion of glacierized area. Osmonov et al. (2013) studied 1,310 glaciers in the Upper Aksu Basin which covered $2,055 \pm 41.1 \mathrm{~km}^{2}$ (ca. $18 \%$ of the entire basin) in 1990 that shrank by $77.1 \pm 57.1 \mathrm{~km}^{2}(0.19 \pm 0.14 \%$ per year $)$ by 2010. The lower reaches of the Aksu River Basin support oases with large areas of irrigated agriculture located upstream and downstream of the gauge Xidaqiao.

The availability of observation records in the Aksu River Basin is not satisfactory, for a variety of reasons. The Aksu is an international river, whose catchment is shared by Kyrgyzstan and China. Due to the international nature of the basin and restrictive data policy, data are not easily available and shared with foreign researchers. Moreover, systemic transformation in the region, from centrally planned economy to market economy, resulted in shrinkage of environmental monitoring. For instance, due to funding problems, fewer observation stations are maintained in Newly Independent States than in the former republics of the Soviet Union (Unger-Shayesteh et al. 2013). Even some long time series of records were interrupted. Furthermore, as the headwater areas are in high, uninhabited, mountainous terrain, rivers are poorly gauged and there is only patchy information on glacier mass balances (see also Krysanova et al. 2014). This data scarcity raises questions of representativeness-deriving spatial aggregates involves high uncertainties.

Climate data for the Chinese part of the basin were provided by the National Climate Centre, China Meteorological Administration (CMA) as daily dataset of minimum, maximum, and mean temperatures and precipitation at a $0.25^{\circ}$ grid for the period $1961-2010$. However, the climate stations in China are located mainly at lower altitudes, and interpolation or extrapolation to higher altitudes introduces considerable uncertainties. In the situation of scarcity of ground observation data, extensive use was made of gridded data sets produced in international 
research projects, such as the meteorological forcing dataset (based on the reanalysis data set ERA-40) "WATCH Forcing Data 20th Century" from the WATCH project (Weedon et al. 2011; http://www.eu-watch.org/) at a spatial resolution of $0.5^{\circ}$ that was used for the Kyrgyz part of the Aksu River Basin, and also for the Chinese part for air humidity and solar radiation parameters. Five variables available at 6-h resolution and five variables at 3-h resolution were aggregated to daily values and used in the present analysis. Mean monthly temperature series were computed for the sub-basins based on CRU 3.1 data set (Harris et al. 2013) with $0.5^{\circ}$ spatial resolution. Monthly precipitation sums for sub-basins were compiled using the GPCC v.6 (http://gpcc.dwd.de) dataset. Daily river discharge data for the period 1964-1987 for the stations Xiehela, Shaliguilanke and Xidaqiao were obtained from the Hydrological Yearbook published by the Chinese Ministry of Water Resources. In addition, monthly river discharge data for these stations were available for a longer period, from 1957 until 2004 (Wang 2006).

\section{Changes in climate: temperature and precipitation}

In the present study, a trend analysis of temperature and precipitation in the Aksu River basin was performed using temporally and spatially aggregated data, namely: annual data averaged over three sub-basins. Trends in time series are sensitive to the selection of the investigation period and the start and end years. Therefore, the analysis of trends in mean annual temperature and total annual precipitation was done for multiple periods with different start and end years
Fig. 2 Multiple trend analyses for mean annual air temperature and annual precipitation for Xidaqiao, Shaliguilanke and Xiehela subcatchments. The colour legend indicates the change in temperature and precipitation in ${ }^{\circ} \mathrm{C}$ and $\mathrm{mm}$ per decade, respectively. Blue and black contours delineate areas of significant trends at 1 and $5 \%$ significance level, respectively
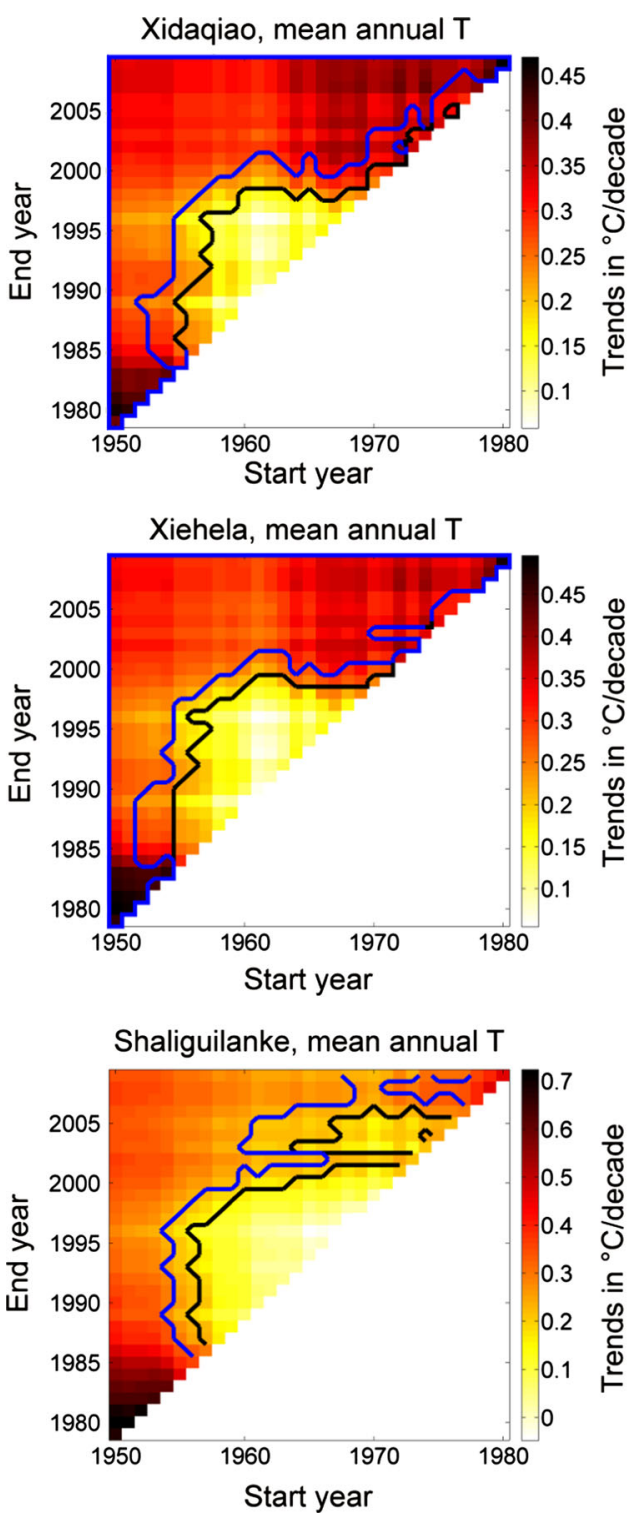
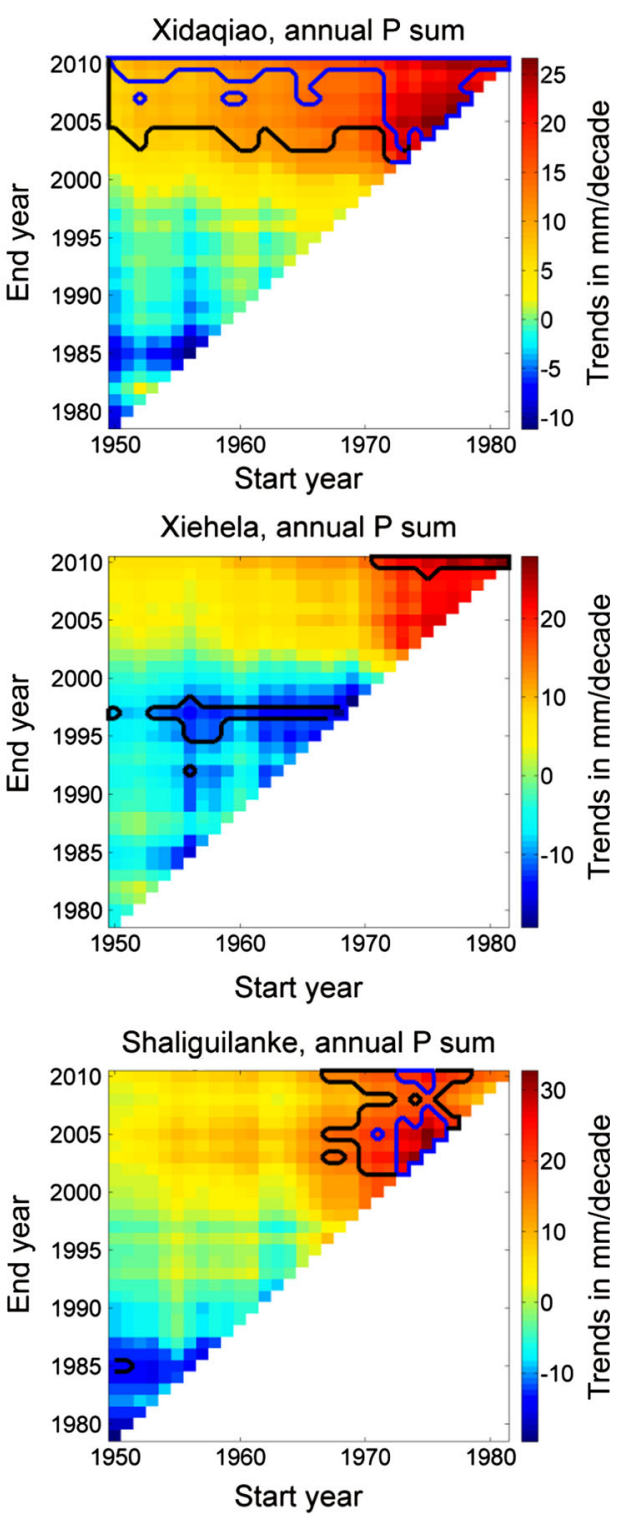
Fig. 3 Multiple trend analyses for mean seasonal air temperature in a summer halfyear (April-September) and b winter half-year (OctoberMarch), c seasonal precipitation sum for summer half-year for the Shaliguilanke subcatchment and $\mathbf{d}$ mean seasonal discharge at gauge Shaliguilanke. The colour legend indicates the change in temperature and precipitation in ${ }^{\circ} \mathrm{C}$ and $\mathrm{mm}$ per decade, respectively, and relative change in discharge with respect to the mean in the respective period. Blue and black contours delineate areas of significant trends at 1 and $5 \%$ significance level, respectively
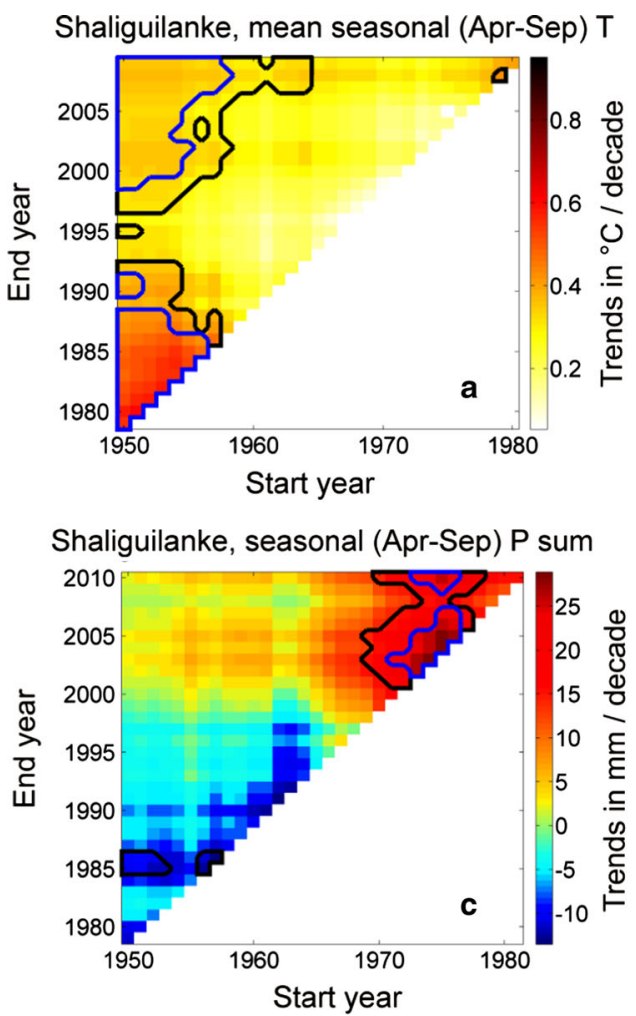

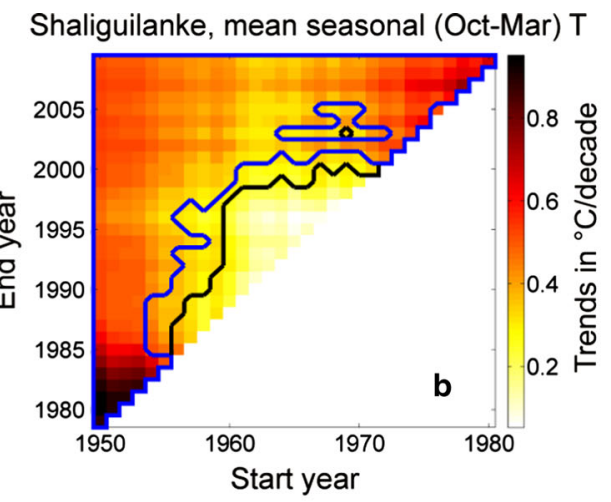

Shaliguilanke, mean seasonal (Apr-Sep) Q

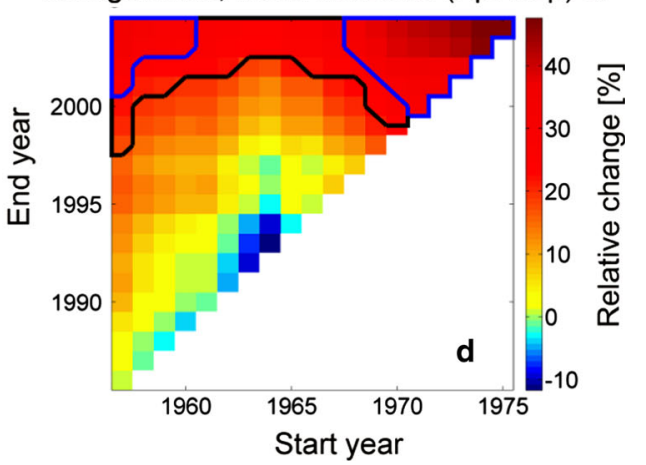

extending the previous trend analyses studies. Trend significance was tested with the non-parametric Mann-Kendall test (Kendall 1975), with significance levels of 5 and $1 \%$. We analysed trends in mean annual temperature and annual precipitation regionalised for three sub-basins Xidaqiao, Xiehela and Shaliguilanke (Fig. 1) using CRU 3.1 temperature and GPCC v.6 precipitation datasets. The multiple trends were investigated for time series at least 30 years in length and changes are presented in terms of temperature and precipitation change in ${ }^{\circ} \mathrm{C} /$ decade and $\mathrm{mm} /$ decade. The time series were pre-whitened to remove the lag-1 correlation which may affect the significance test.

Figure 2 presents multiple trend analyses with Sen's slope estimator for periods with different start and end years. The results indicate strong significant positive trends in air temperature with a rate of $0.2-0.7^{\circ} \mathrm{C}$ per decade, which are nearly persistent for all periods with different start and end years. In particular, in the period from 1950 to 1980 and from the 1970s to the mid 2000s, the trends in mean annual temperature are strong. This increase is dominated by a rise in temperature during the winter halfyear (October-March) as exemplarily shown in Fig. 3a, b for the gauge Shaliguilanke. This pattern has already been observed for Northern (Bolch 2007; Zhang et al. 2009) and Central Tien Shan (Giese and Moßig 2004; Kriegel et al. 2013); the related studies are extensively reviewed by Unger-Shayesteh et al. (2013). A more severe increase in winter temperatures is expected to continue in future according to the regional climate model projections for this region (Mannig et al. 2013). The temperature increase in the winter half-year is, however, often not melt-effective, as the temperatures remain below the melting point. In the Aksu basin also significant positive trends in mean warm half-year (April-September) temperature were detected for all sub-basins in the period from the 1950 s to the 2000 s (Fig. 3a) and can partly explain the increasing discharges over the same periods (Figs. 3d, 4).

Trends in total annual precipitation are mainly insignificant for all sub-basins for the majority of periods, but become significantly positive for the periods from the 1970s till the 2000s in Shaliguilanke and Xiehela basins. In Xidaqiao, the increasing trends are significant for all periods starting from 1950 or later till the late $\sim 2000$ s. This increase in annual precipitation is mainly dominated by an increase in summer precipitation (April-September) (Fig. 3c for gauge Shaliguilanke), when the largest share of precipitation occurs.

\section{Changes in river flow}

The flow regime of the River Aksu is dominated by snow and glacier melt. Analysis of data shows that more than $80 \%$ of the annual discharge of the River Aksu occurs in the warm season from April to September. In the cold season, the flow of the rivers Aksu and Tarim can be very low (Fig. 4). 


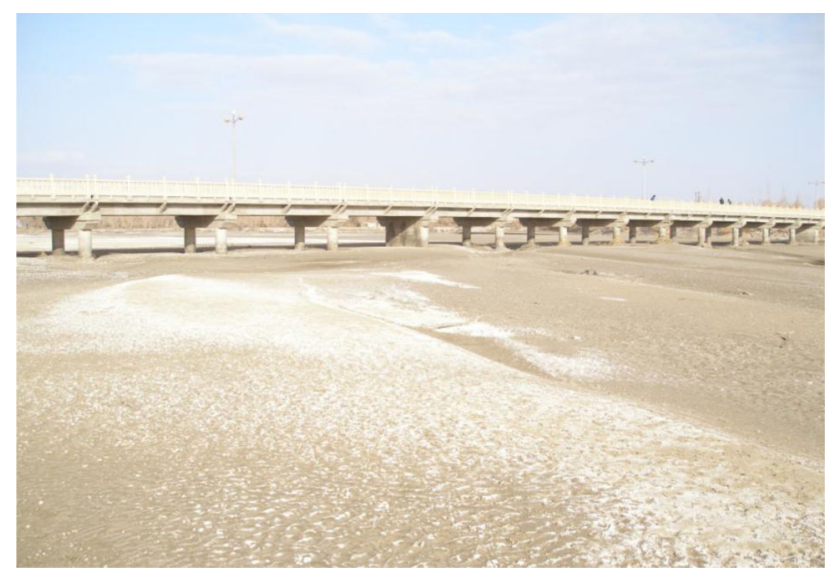

Fig. 4 In November, the flow in the River Aksu, tributary to the large River Tarim is very low. Hence the broad channel of the Aksu, that can fill during abundant snow and glacial melt or a GLOF event, is nearly dry, with salt-crusted river bed (Photo: Z. W. Kundzewicz, November 2008)

In the Xidaqiao sub-basin, considerable volume of water is withdrawn for irrigation use. The discharge is reduced by $18 \%$ until Xidaqiao compared to the input from two headwater tributaries, i.e. by $\sim 1,324 \mathrm{mln} \mathrm{m}^{3} /$ year. Much more water is used downstream of Xidaqiao (cf. Huang et al. 2014). Hence, the average annual discharge of the River Aksu at Xidaqiao is notably lower than the sum of discharges of the two upper tributaries, Xiehela and Shaliguilanke (Fig. 5). This is particularly evident during the warm season from April to September-the major water withdrawal period. The analysis performed in the previous study (Krysanova et al. 2014) for the period 1997-2004 led to the following finding: the average annual discharge of the two upper tributaries was about $23 \%$ higher than the discharge at the lower gauge Xidaqiao in this period.

In this study, the trend analysis in river discharge is extended by exploring trends in mean annual discharge at three gauges for multiple periods with different start and end years. Detection of trends for respective gauges at subbasins outlets Xiehela, Shaliguilanke, and Xidaqiao, was carried out with the help of multiple trend analysis.

The time series were pre-whitened to remove the lag-1 correlation and the trend slope was estimated by a KendallTheil robust line approach based on the Sen's slope estimator (Sen 1968). Figure 6 presents multiple trend analyses for periods with different start and end years. Significant upward trends are found for time periods ending in the beginning or mid of the 2000s for the gauge Xiehela and Shaliguilanke. The upward trends in mean annual flow at these upstream gauges translate into a similar trend pattern at gauge Xidaqiao with significantly increasing trends in the periods ending after the year 2000. As for temperature changes, the increase in mean annual flow is primarily dominated by increasing summer flows as shown exemplarily for gauge Shaliguilanke (Fig. 3d). The summer flows constitute the largest portion of water over the year.

\section{Links between climatic and hydrological variables}

This section presents links between climatic variables and river flow, found using several approaches at various temporal scales: correlations using daily, monthly and seasonal data and climate elasticity of streamflow.

Correlation between climatic and hydrological variables using daily data

Links between river discharge and climatic variables, temperature and precipitation, for two headwater subcatchments Xiehela and Shaliguilanke were analysed at daily time steps. Climatic variables were averaged over the corresponding subcatchment areas. Only a low and not statistically significant correlation was found between daily river discharge and daily precipitation for both stations. Lack of a fast response of discharge to precipitation can be explained by a higher importance of melting water from snow and ice feeding the river compared to precipitation.

The correlation between daily temperature and daily river discharge for both subcatchments was high and statistically significant, but lower for the Shaliguilanke subcatchment. The Spearman correlation coefficients for the whole period were 0.71 and 0.60 without time delay, and 0.83 and 0.66 with 2 days time delay for the Xiehela and Shaliguilanke, respectively. This can be explained by a high importance of glacier and snow melt processes in the basin, and a notably higher share of glacier cover in the Xiehela subcatchment as compared to Shaliguilanke subcatchment.

A further analysis of temperature and discharge time series for Xiehela in the period 1965-1987 (see Krysanova et al. 2014) revealed a visually noticeable positive linkage between temperature and discharge peaks in summer. Typically, discharge peaks follow temperature peaks with the delay of 1-3 days. It was found that a strong and highly statistically significant positive correlation (level 0.001) exists between temperature and river discharge for the longer periods in summer with no delay and with delays of 1-3 days. The coefficients of correlation tend to increase from the " 0 days delay" case to the " 2 days delay" case (e.g. reflected by the increase of the mean Spearman coefficient for the whole period from 0.71 to 0.83 ). The results are stable for all years. The high positive correlation between daily time series of temperature and streamflow is rather unusual for river basins in the temperate zone. However, it is understandable for the Xiehela gauge in the 
Fig. 5 The summer flow of the River Aksu at Xidaqiao, compared to the sum of flows of tributaries at Xiehela and

Shaliguilanke. Flow at Xidaqiao (top), sum of tributaries (middle), difference between flow at Xidaqiao and the sum of tributaries (bottom)

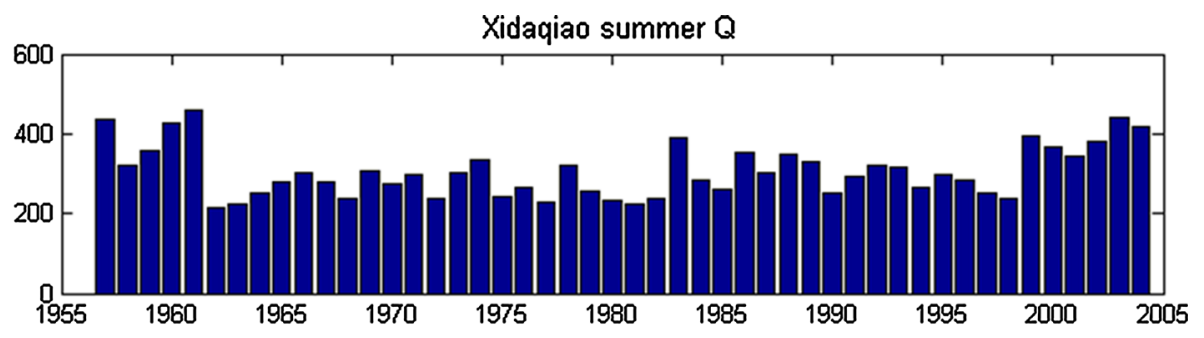

Xiehela + Shalquilanke summer $Q$

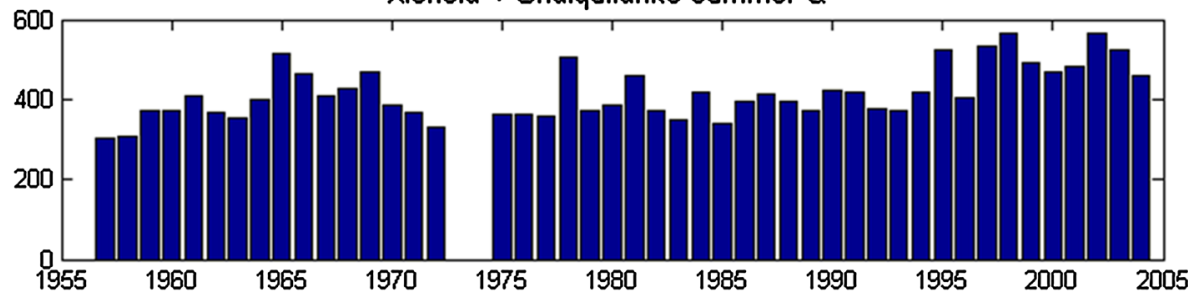

Xidaqiao - (Xiehela + Shalquilanke) summer $Q$

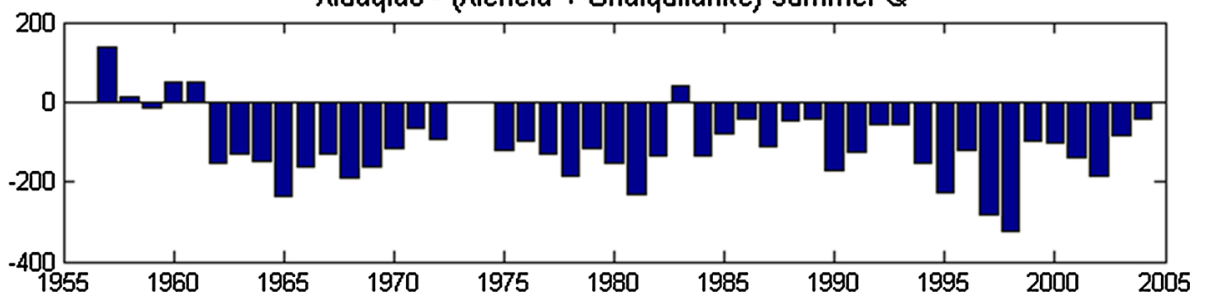

Fig. 6 Multiple trend analyses for mean annual discharge at gauges Xidaqiao, Shaliguilanke and Xiehela. The colour legend indicates the relative change in discharge with respect to the mean in the specific period. Blue and black contours delineate areas of significant trends at 1 and $5 \%$ significance level, respectively
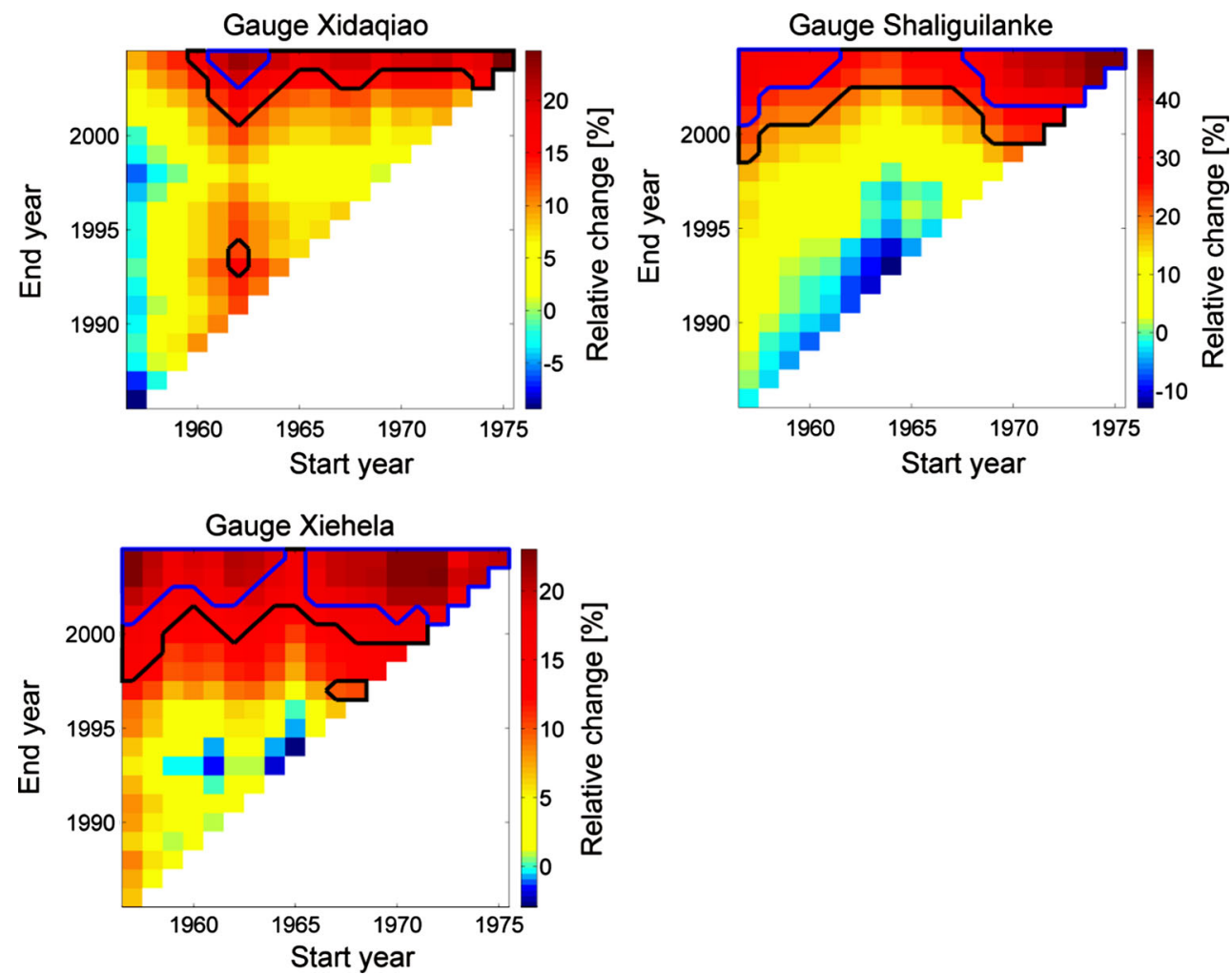

Aksu River Basin, where water is coming mostly from temperature-driven snow and glacier melt in the high mountains.
There were short periods with high discharge values at the end of summer or beginning of autumn (every year, mostly in August) found in the Xiehela station, where 
correlation was not evident. Analysis confirmed that the correlation between $T$ and $Q$ in these periods was low and not statistically significant. It was possible to find even a negative connection for some short intervals, when discharge peaks followed a decline in temperature.

The explanation for short periods with high peaks in river discharge at the end of the warm season, when temperature starts to decline and positive correlation between $T$ and $Q$ breaks, has been found based on literature data, analysis of observed data and modelling results (Glazirin 2010; Krysanova et al. 2014; Wortmann et al. 2014). Glazirin (2010) provided a review of the outbursts of the ice-dammed Lake Merzbacher located in the headwater part of the River Aksu, and listed dates of witnessed outbursts. In summer, melting water from the northern Inylchek Valley fills the lake. When the system of englacial channels in the damming glacier opens, water flows through the main Inylchek Glacier westwards into the Inylchek Valley. From there it flows further to the Chinese part of the basin and some $150 \mathrm{~km}$ downstream it reaches the Xiehela gauging station. The Glacial Lake Outburst Floods (GLOFs) occur mainly in August or September, but the exact timing and volume of water are difficult to forecast, although recently a method based on satellite assessment of lake area and floating ice in the Lake Merzbacher has been proposed for prediction of timing of GLOFs (Xie et al. 2013). Rarely, outbursts occur in spring or twice in a single year. The analysis confirmed that the short periods in August-September with breaking correlation are the periods of GLOFs (Krysanova et al. 2014). A method for the identification of GLOFs was suggested using the observed discharge at Xiehela and modelling results (Wortmann et al. 2014).

\section{Interdependencies at different temporal scales}

Figure 7 presents scatter plots illustrating interdependence between temperature, precipitation, and river discharge at different temporal resolution, for summer, following the technique of Exploratory Data Analysis. Annual and monthly values refer to the period 1961-2001, while for daily values only the period 1964-1987 was available.

It is interesting to note the similarities and differences in the interdependencies between the sub-basins of Xiehela and Shaliguilanke when comparing the different time scales. Both catchments show a very similar behaviour at the daily and monthly resolution. Daily summer values of temperature and discharge are positively correlated with high, and statistically significant, Spearman rank correlation coefficients of 0.86 and 0.76 , and discharge increases non-linearly with increasing temperature. On the contrary, there are very low correlations coefficients of approx. 0.23 between daily discharge and daily precipitation values.

At the monthly scale, discharge is again positively correlated with temperature indicated by high, and statistically significant, correlation coefficients of 0.93 and 0.81 . In addition, discharge is significantly positively correlated with precipitation as moderate correlation coefficients of 0.41 and 0.51 show.

These similarities in interdependence between temperature, precipitation and discharge between the two subcatchments disappear at the seasonal resolution. Though for Xiehela the high positive correlation between temperature and discharge is kept (0.79), it breaks down for Shaliguilanke. At the same time, there is a significant positive correlation between discharge and precipitation for Shaliguilanke at the seasonal scale (Spearman's rank correlation 0.48 , significant at $1 \%$-level).

For Xiehela with the large fraction of glacier area, temperature dominates the streamflow behaviour at the daily, monthly and seasonal scale. Changes in precipitation are not transferred to correspondent changes in discharge, since precipitation is stored in glacier and snow areas, and streamflow is controlled by temperature. For Shaliguilanke, precipitation plays the dominant role at the seasonal time scale. Due to the much smaller glacier area and the lower topography, the effect of precipitation storage across years is small and precipitation in summer is mostly transferred to streamflow in the same season. Hence, summers with higher precipitation also show higher discharge.

\section{Correlation analysis for monthly data with time delay}

Time series of monthly subcatchment precipitation averages for the Xiehela, Shaliguilanke, and Xidaqiao subcatchments and of monthly average discharges recorded at the corresponding hydrological stations were examined to check the assumption of normal distribution using the Kolmogorov-Smirnov test. None of the tested time series is normally distributed. Accordingly, Spearman's and Kendall's rank correlation coefficients were calculated to assess the relationship between monthly subcatchment precipitation (CMA and WATCH data) and monthly discharge at the respective stations (data from CMWR, i.e. China Ministry of Water Resources) with time delays between 0 and 6 months. The correlation coefficients were calculated based on data for the period 1964-1987.

The results of the correlation analyses are presented in Table 1. Highest correlation coefficients were detected for a time delay of 1 month. This is also visualised in Fig. 8, indicating that a peak (trough) in discharge follows a peak (trough) in precipitation with a delay of about 1 month. The positive correlation turns into negative starting with a time delay of 4 months. For example the winter months with low precipitation are negatively correlated with the summer months showing the highest discharge. The very high average discharges (as compared to precipitation totals) at the hydrological stations Xiehela and Xidaqiao in 
Xiehela
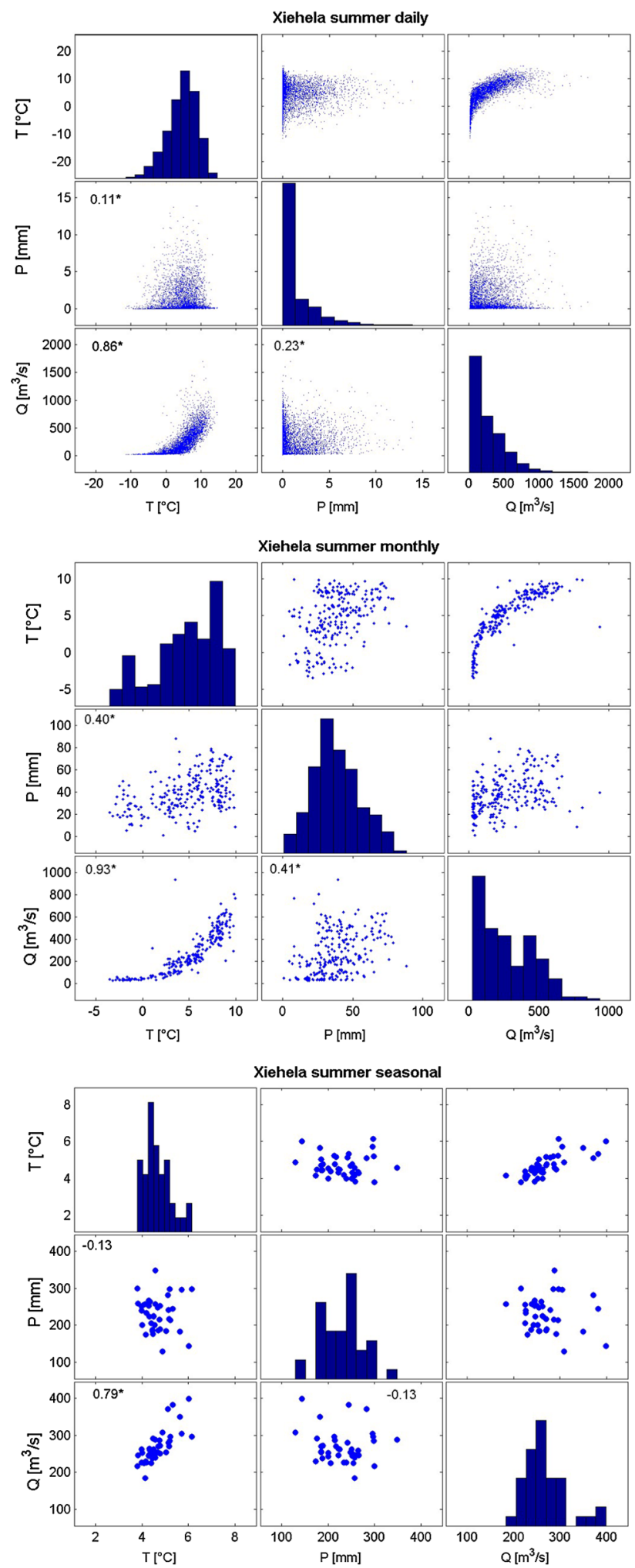

Shaliguilanke
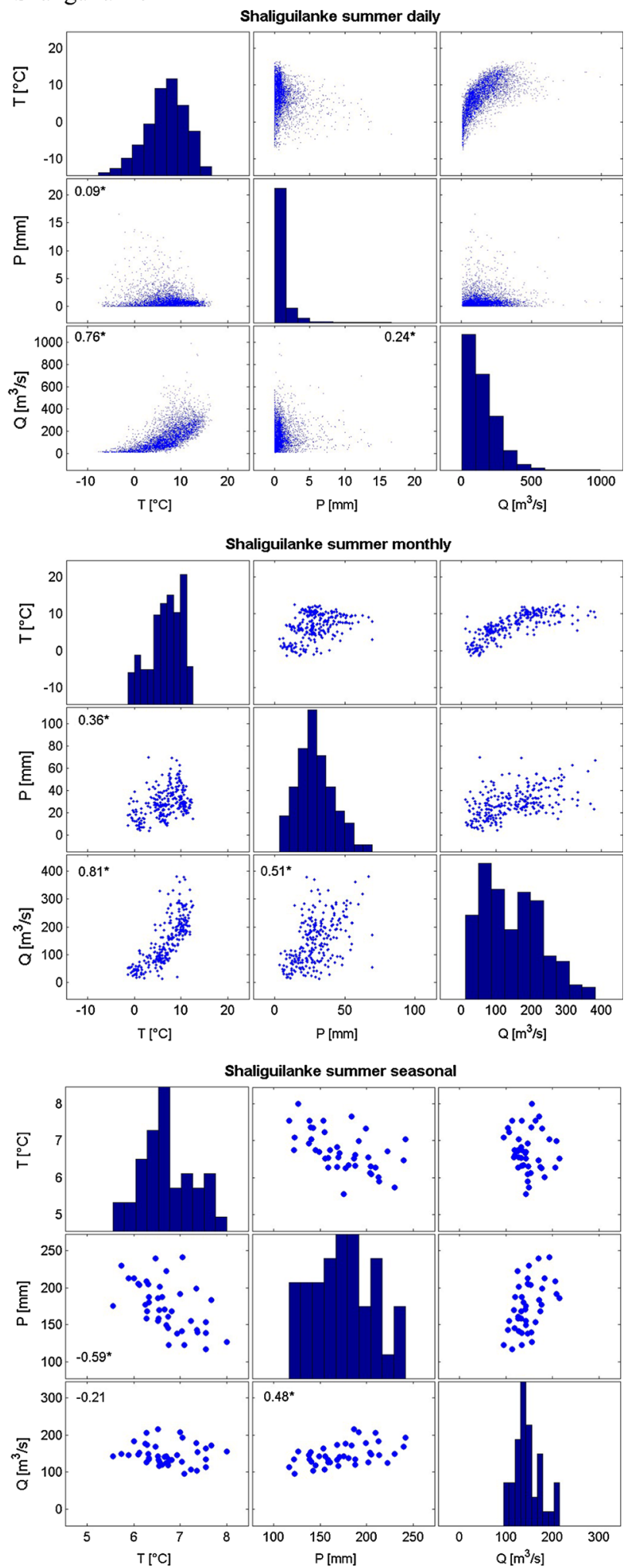

Fig. 7 Scatter plots illustrating interdependence between temperature, precipitation, and river discharge at daily (top), monthly (middle) and seasonal (bottom) resolution for Xiehela (left) and Shaliguilanke (right). The numbers in the plots give the Spearman rank correlation coefficient 
Table 1 Correlation between monthly subcatchment precipitation averages and Aksu River discharge in three stations, for the period 1964-1987

Bold correlation is significant at the level below 0.01

Fig. 8 Time series of monthly subcatchment precipitation and river discharge at a Xiehela (S1), b Shaliguilanke (S2), and c Xidaqiao (S3) for the period from January 1968 to December 1972

\begin{tabular}{lllllllll}
\hline Data & $r$ & \multicolumn{9}{l}{ Time delay (months) } \\
\cline { 3 - 9 } & & 0 & 1 & 2 & 3 & 4 & 5 & 6 \\
\hline \multirow{2}{*}{ Xiehela } & Spearman & $\mathbf{0 . 7 6 3}$ & $\mathbf{0 . 8 3 6}$ & $\mathbf{0 . 7 0 2}$ & $\mathbf{0 . 3 5 6}$ & -0.053 & $\mathbf{- 0 . 4 6 5}$ & $\mathbf{- 0 . 7 4 8}$ \\
& Kendall & $\mathbf{0 . 5 5 2}$ & $\mathbf{0 . 6 2 6}$ & $\mathbf{0 . 4 9 3}$ & $\mathbf{0 . 2 3 3}$ & -0.027 & $\mathbf{- 0 . 3 0 1}$ & $\mathbf{- 0 . 5 3 5}$ \\
\multirow{2}{*}{ Shaliguilanke } & Spearman & $\mathbf{0 . 7 3 3}$ & $\mathbf{0 . 8 0 9}$ & $\mathbf{0 . 6 7}$ & $\mathbf{0 . 3 8 1}$ & -0.02 & $\mathbf{- 0 . 4 1 9}$ & $\mathbf{- 0 . 7 1 7}$ \\
& Kendall & $\mathbf{0 . 5 2}$ & $\mathbf{0 . 5 9 3}$ & $\mathbf{0 . 4 7}$ & $\mathbf{0 . 2 5 8}$ & 0.001 & $\mathbf{- 0 . 2 6 2}$ & $\mathbf{- 0 . 4 9 4}$ \\
Xidaqiao & Spearman & $\mathbf{0 . 5 0 8}$ & $\mathbf{0 . 6 3 6}$ & $\mathbf{0 . 6 3 6}$ & $\mathbf{0 . 4 7 7}$ & $\mathbf{0 . 2 0 4}$ & -0.131 & $\mathbf{- 0 . 4 2 4}$ \\
& Kendall & $\mathbf{0 . 3 2 9}$ & $\mathbf{0 . 4 2 9}$ & $\mathbf{0 . 4 3 9}$ & $\mathbf{0 . 3 2 4}$ & $\mathbf{0 . 1 3 8}$ & -0.069 & $\mathbf{- 0 . 2 7 7}$ \\
\hline
\end{tabular}
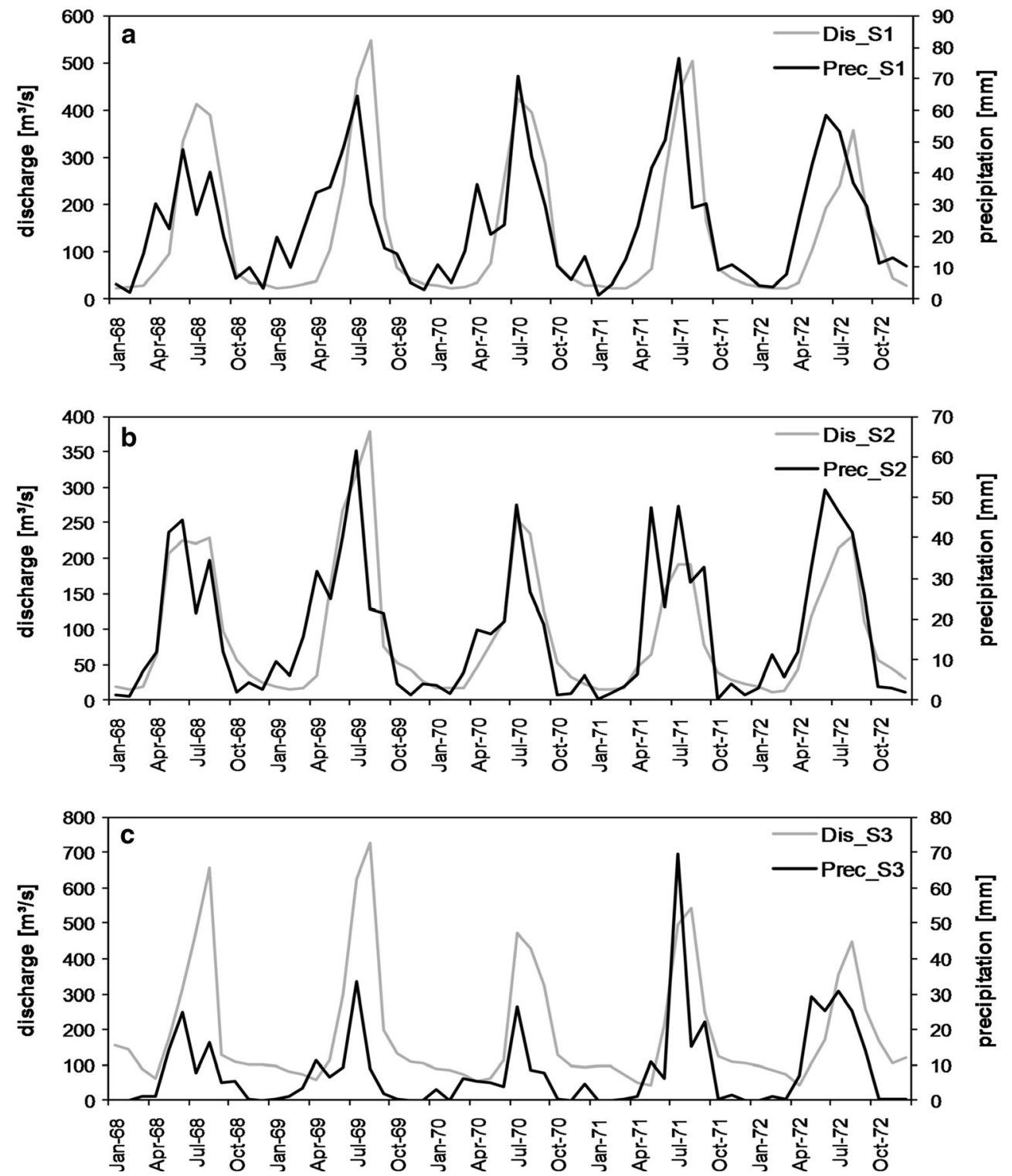

the summers of 1968 and 1969 (Fig. 8a, c) are the results of GLOFs.

Comparing the results obtained here with those from Sect. 5.2, some differences become apparent. In Sect. 5.2 precipitation data for the summer season were used, while we employed data from all months of the year here. Whereas in Sect. 5.2 a statistically significant correlation between monthly precipitation and discharge was found for Xiehela and Shaliguilanke with moderate correlation coefficients, it is confirmed here, yet with higher 
correlation coefficients (Table 1, time delay 0). During the summer, the response of discharge to temperature is pronounced due to the high importance of meltwater feeding the river. Accordingly, during the summer season the influence of precipitation on discharge is weaker than in other seasons. However, using data from all months of the year, the relationship between precipitation and discharge becomes evident.

\section{Climate elasticity of streamflow}

Climate elasticity of streamflow (cf. Schaake 1990) describes how sensitively streamflow responds to changes in climate variables. Typically, studies on climate elasticity of streamflow estimate the sensitivity of streamflow to changes in precipitation. Precipitation elasticity of streamflow is larger than 1 , if a $1 \%$ change in precipitation leads to more than a $1 \%$ change in discharge, and smaller than 1 , if a $1 \%$ change in precipitation leads to less than a $1 \%$ streamflow change. Negative values of climate elasticity represent the situation when an increase in precipitation is associated with a decrease in discharge and a decrease in precipitation is associated with an increase in discharge. The higher the elasticity, the more sensitive is a catchment to precipitation changes (and the more reasons for concern about water resources management exist).

Fu et al. (2007) criticised the widespread use of precipitation elasticity focusing only on changes in precipitation and neglecting sensitivity to temperature. Indeed, for the Xiehela subcatchment analysed in this study, the discharge is driven by changes in temperature rather than changes in precipitation. Fu et al. (2007) and Risbey and Entekhabi (1996) visualised the sensitivity of streamflow to changes in both precipitation and temperature in a twodimensional contour plot.

A climate elasticity study was conducted for subcatchments of the River Aksu, based on the warmer half-year (April-September) anomalies of temperature, precipitation, and streamflow. Temperature and precipitation data are averaged over the subcatchment area. We restrict this analysis to the warmer half-year, since precipitation and discharge are much higher than in the colder half-year. Precipitation is approx. fourfold higher in the warmer halfyear in both subcatchments, and discharge is 6.8- and 6-fold higher in Xiehela and Shaliguilanke, respectively. Hence, there is little precipitation in the colder half-year, and moreover, a large fraction of precipitation is stored as snow and ice and does not contribute to runoff during the winter months.

For each warmer half-year of the observation period, the departure from the mean value (in the warmer half-year of the period 1957-2004) is calculated for temperature, precipitation and discharge. The discharge departure is plotted on a precipitation-temperature plane, and interpolated (with kriging using a spherical semivariogram) to a regular grid.

Contour plots were established for subcatchments of interest in the present case study. These plots (Fig. 9) illustrate the percentage change in discharge as a function of absolute temperature change and percentage change in precipitation.

Figure 9 shows the climate elasticity of streamflow for subcatchments of the River Aksu. For the Xiehela case (Fig. 9a), for most parts of the precipitation-temperature plane, climate elasticity is smaller than 1 . There are areas where climate elasticity is smaller than zero, for example in the upper left part. Here a decrease in precipitation is associated with an increase in discharge. However, temperature was found to have significantly increased, and this increase in temperature dominates the streamflow response. Overall, it can be stated that changes in streamflow are dominated by changes in temperature. The change in streamflow is more systematic and the gradients are stronger along the temperature axis. The influence of precipitation is less consistent and less important.

Climate elasticity for Shaliguilanke (Fig. 9b) shows a different pattern. Although many areas have a climate elasticity smaller than 1 , there are also extended areas with elasticity values greater than 1 . Overall, this plot shows that seasonal streamflow response to changes in climate in Shaliguilanke is more influenced by changes in precipitation compared to Xiehela. The contour lines show a more systematic change and stronger gradients along the precipitation axis.

Although overall patterns are obvious in the contour plots of Fig. 9a, b, some isolines are rather erratic. To an even greater extent this is also true for the plots for the subcatchments of Xidaqiao, heavily influenced by water abstractions for irrigation (Fig. 9c) and the sum of Xiehela and Shaliguilanke (Fig. 9d). In summary, there is significant heterogeneity in the temperature-precipitation-discharge relationships in both catchments. Hence, this analysis gives only a rough indication of the seasonal streamflow response to changes in climate.

\section{Perspectives for seasonal forecasting}

Even though modulated by other factors such as human interference, GLOFs, and temperature (being of particular importance for runoff generation in glacierized areas), precipitation still is a key factor influencing discharge. In the first part of this section, evidence about the relationship between precipitation and discharge is provided by means of a correlation analysis with time delay using monthly data for the whole year. In addition, differences between 
a

Xiehela

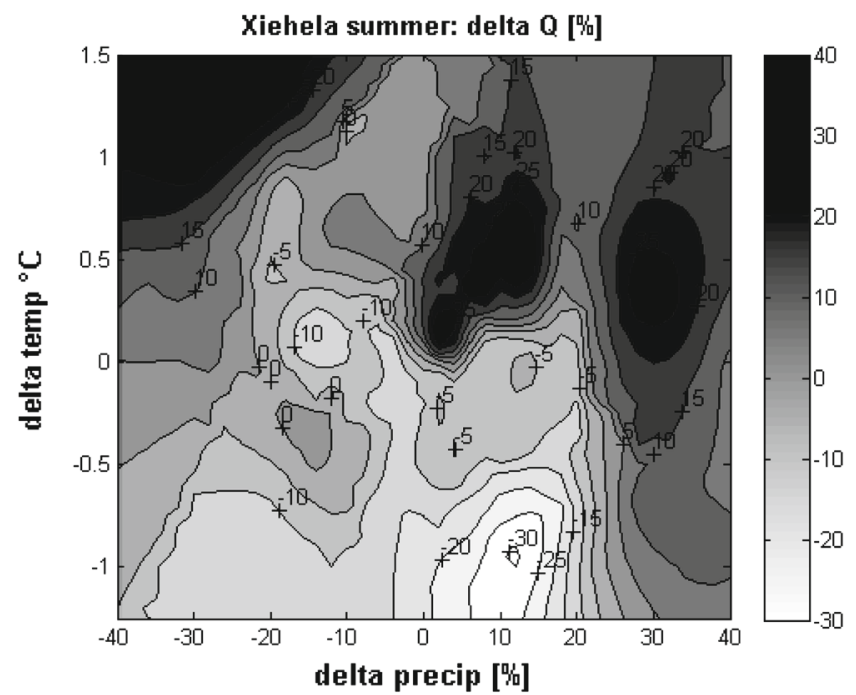

c Xidaqiao
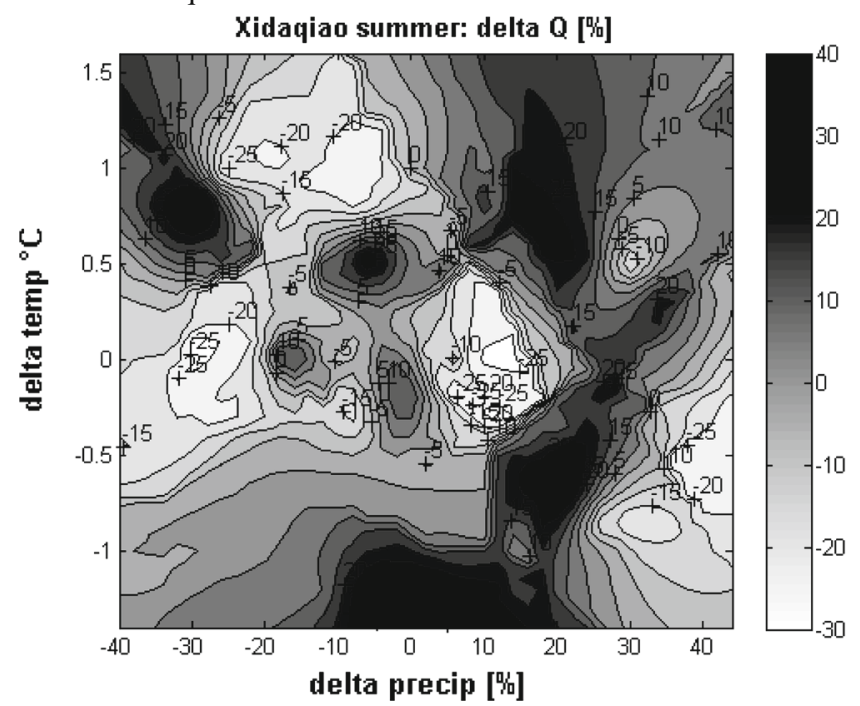

Fig. 9 Climate elasticity of streamflow for sub-basins of the River Aksu b Shaliguilanke

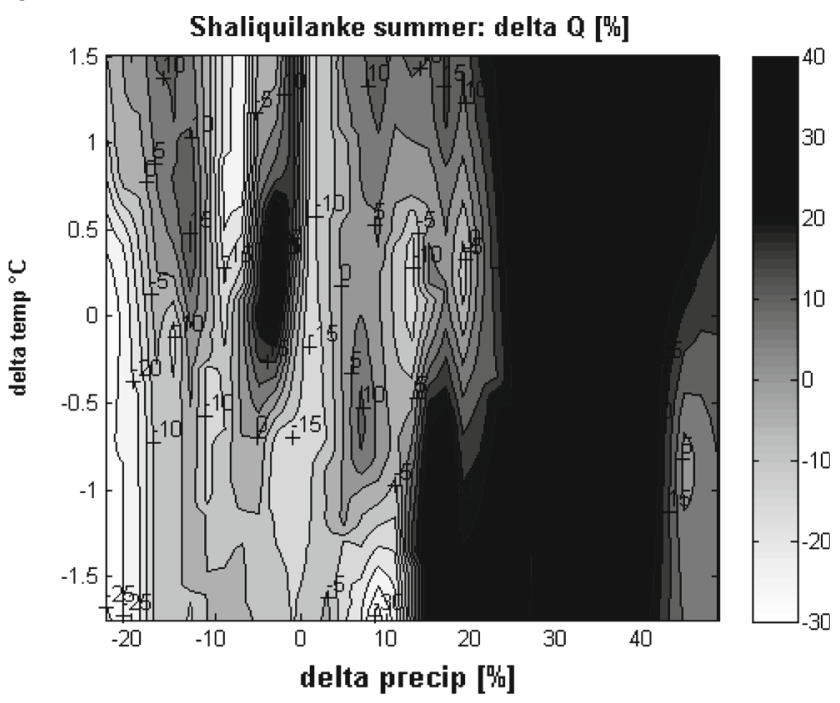

d Xiehela + Shaliguilanke

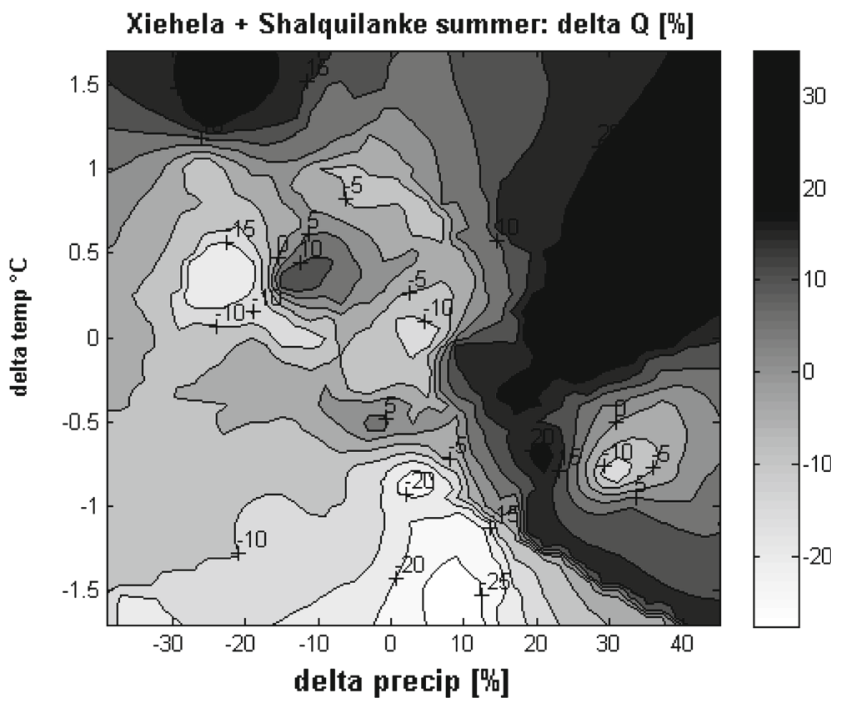

the results obtained here and the results of Exploratory Data Analysis are briefly discussed and explained. The second part of this section includes an approach to seasonal forecasting of precipitation in the Shaliguilanke subcatchment and introduces climatic indices that proved to be relevant for forecasting.

Seasonal precipitation forecasts are an important tool for water resources management and planning. Links between appropriate indices and precipitation may prove to be useful for seasonal forecasting procedures. Using the Shaliguilanke subcatchment as example, different climatic indices are introduced that proved to be important for seasonal precipitation forecasts. The Shaliguilanke subcatchment was chosen, as it shows a smaller glacierized area compared to the Xiehela subcatchment and discharge is less influenced by anthropogenic activities, compared to the Xidaqiao subcatchment, where in more recent years discharge decreased due to water extraction for irrigation.

Based on literature research, 31 climate indices (input variables, predictors) were assessed as possibly relevant for seasonal forecasts of precipitation (output variable, predictand) in the Shaliguilanke subcatchment. These climate indices were calculated or obtained in monthly resolution. Table 2 provides an overview of these indices and includes relevant references. As mentioned above, most of the time series are not normally distributed. The most influential indices were identified by a two-step procedure: First, Spearman's and Kendall's rank correlation coefficients between the input variables and the output variable were calculated to identify the optimum time delay. Second, a 
Table 2 Overview of all indices considered as possibly relevant for seasonal precipitation forecasts in the Shaliguilanke subcatchment

\begin{tabular}{|c|c|c|}
\hline Index & Abbreviation & Source \\
\hline North Atlantic Oscillation & NAO_LI & $\begin{array}{l}\text { Introduced by Li et al. (2007); Time series is provided on the } \\
\text { personal webpage of the first author at http://web.lasg.ac.cn/ } \\
\text { staff/ljp/data-NAM-SAM-NAO/NAO.htm }\end{array}$ \\
\hline North Atlantic Oscillation & $\mathrm{NAO}$ & \multirow{10}{*}{$\begin{array}{l}\text { Climate Prediction Center, Camp Springs, Maryland, USA } \\
\text { http://www.cpc.ncep.noaa.gov }\end{array}$} \\
\hline Polar/Eurasia Pattern & POL/EUR & \\
\hline Scandinavia Pattern & SCA & \\
\hline East Atlantic/Western Russia Pattern & EA/WR & \\
\hline East Atlantic Pattern & EA & \\
\hline Arctic Oscillation & $\mathrm{AO}$ & \\
\hline Southern Oscillation Index & SOI & \\
\hline Niño 3 & NINO3 & \\
\hline Niño 4 & NINO4 & \\
\hline Niño 3.4 & NINO34 & \\
\hline Siberian High Intensity & SHI & $\begin{array}{l}\text { Introduced by Gong et al. (2001), own calculation based on } \\
\text { NCEP/NCAR Reanalysis data }\end{array}$ \\
\hline Northern Hemispheric Circumpolar Teleconnection & CGT & $\begin{array}{l}\text { Introduced by Huang et al. (2011); own calculation based on } \\
\text { NCEP/NCAR Reanalysis data }\end{array}$ \\
\hline Westerly Circulation Index & WCI & $\begin{array}{l}\text { Introduced by Wu et al. (2012); own calculation based on } \\
\text { NCEP/NCAR Reanalysis data }\end{array}$ \\
\hline Webster-Yang Monsoon Index & WY_MI & $\begin{array}{l}\text { Introduced by Webster and Yang (1992); own calculation } \\
\text { based on NCEP/NCAR Reanalysis data }\end{array}$ \\
\hline South Asian Monsoon Index & SA_MI & $\begin{array}{l}\text { Introduced by Goswami et al. (1999); own calculation based } \\
\text { on NCEP/NCAR Reanalysis data }\end{array}$ \\
\hline East Asian-Western North Pacific Monsoon Index & EA_WNP_MI & $\begin{array}{l}\text { Introduced by Wang et al. (2008); own calculation based on } \\
\text { NCEP/NCAR Reanalysis data }\end{array}$ \\
\hline 14 different Sea Surface Temperature (SST) indices & & Own calculation based on NOAA_ERSST_V3 data \\
\hline
\end{tabular}

Arctic Ocean, North Atlantic Ocean, Mediterranean Sea,

Black Sea, Caspian Sea and for different parts of the Indian and Pacific Oceans

NCEP/NCAR Reanalysis and NOAA_ERSST_V3 data were provided by the NOAA/OAR/ESRL PSD, Boulder, Colorado, USA from their Web site at http://www.esrl.noaa.gov/psd

stepwise linear regression was carried out to test whether inclusion of an input variable in a model improved the forecasting. Finally, the indices identified as most important for seasonal forecasting and their relationship to precipitation as discussed in the literature are briefly described. Table 3 provides a description of the calculation procedure for each of these important indices.

The largest number of highly significant correlation coefficients and the highest correlation coefficients were detected for a time delay of 4 months. For the input variables identified as being of highest importance in the second step, the results of the correlation analyses are presented in Table 4. The highest values of correlation coefficients, all of which are statistically significant at the 0.01 level, were identified between precipitation averaged over the Shaliguilanke subcatchment and the Siberian High Intensity (SHI), the Western Circulation Index (WCI), and several indices calculated from Sea Surface Temperatures (SSTs). The WCI and the SST indices are linked to precipitation the whole year long whereas teleconnection
Table 3 Climate indices identified as most important for seasonal precipitation forecasts in the Shaliguilanke subcatchment along with a description of their calculation

\begin{tabular}{|c|c|c|}
\hline Index & Abbreviation & Calculation Procedure \\
\hline $\begin{array}{l}\text { Siberian High } \\
\text { Intensity }\end{array}$ & SHI & $\begin{array}{l}\text { Mean SLP averaged over the centre } \\
\text { of the anticyclone }\left(40^{\circ} \mathrm{N}-60^{\circ} \mathrm{N} \text {, }\right. \\
\left.70^{\circ} \mathrm{E}-120^{\circ} \mathrm{E}\right)(\text { Gong et al. } 2001)\end{array}$ \\
\hline $\begin{array}{l}\text { Westerly } \\
\text { Circulation } \\
\text { Index }\end{array}$ & WCI & $\begin{array}{l}\text { Difference in } 500 \mathrm{hPa} \text { geopotential } \\
\text { height }(\mathrm{GPH}) \text { between } 35^{\circ} \mathrm{N} \text { and } \\
55^{\circ} \mathrm{N} \text { averaged over the longitudes } \\
\text { of } 40^{\circ} \mathrm{E}-100^{\circ} \mathrm{E}(\mathrm{Wu} \text { et al. } 2012)\end{array}$ \\
\hline $\begin{array}{l}\text { SST Arctic } \\
\text { Ocean }\end{array}$ & SST_ArctOc & $\begin{array}{l}\text { Averaged SSTs between } 65^{\circ} \mathrm{N}-89^{\circ} \mathrm{N} \\
\text { and } 180^{\circ} \mathrm{W}-180^{\circ} \mathrm{E} \text { (maximum } \\
\text { extension) }\end{array}$ \\
\hline $\begin{array}{l}\text { SST North } \\
\text { Atlantic } \\
\text { Ocean }\end{array}$ & SST_NAtlOc & $\begin{array}{l}\text { Averaged SSTs between } 1^{\circ} \mathrm{S}-65^{\circ} \mathrm{N} \\
\text { and } 81^{\circ} \mathrm{W}-1^{\circ} \mathrm{W} \text { (maximum } \\
\text { extension) }\end{array}$ \\
\hline
\end{tabular}

indices such as the Polar/Eurasia Pattern (POL/EUR) or the monsoon indices are linked to precipitation only during part of the year. Even though the coupling of the SHI and 
Table 4 Correlation between climatic indices identified as being of highest importance for seasonal forecasts and Shaliguilanke subcatchment precipitation (CMA and WATCH data) for the period from 1964 to 1987

Bold significant at the level below 0.01

\begin{tabular}{llllllllr}
\hline Data & $r$ & \multicolumn{7}{l}{ Time delay (months) } \\
\cline { 3 - 9 } & & 0 & 1 & 2 & 3 & 4 & 5 & 6 \\
\hline \multirow{2}{*}{ SHI } & Spearman & $\mathbf{- 0 . 8 1 9}$ & $\mathbf{- 0 . 6 6 3}$ & $\mathbf{- 0 . 3 0 2}$ & 0.143 & $\mathbf{0 . 5 3 8}$ & $\mathbf{0 . 7 7 6}$ & $\mathbf{0 . 8 2 9}$ \\
& Kendall & $\mathbf{- 0 . 6}$ & $\mathbf{- 0 . 4 4 2}$ & $\mathbf{- 0 . 1 8 5}$ & 0.096 & $\mathbf{0 . 3 6 1}$ & $\mathbf{0 . 5 5 8}$ & $\mathbf{0 . 6 1 1}$ \\
\multirow{2}{*}{ WCI } & Spearman & $\mathbf{- 0 . 6 0 4}$ & $\mathbf{- 0 . 4 4 8}$ & $\mathbf{- 0 . 2 2 7}$ & 0.04 & $\mathbf{0 . 3 1 2}$ & $\mathbf{0 . 4 6 7}$ & $\mathbf{0 . 5 1 2}$ \\
& Kendall & $\mathbf{- 0 . 4 2 5}$ & $\mathbf{- 0 . 3 0 9}$ & $\mathbf{- 0 . 1 4 9}$ & 0.028 & $\mathbf{0 . 2 0 5}$ & $\mathbf{0 . 3 0 6}$ & $\mathbf{0 . 3 5 6}$ \\
\multirow{2}{*}{ SST_AO } & Spearman & $\mathbf{0 . 4 2 1}$ & -0.016 & $\mathbf{- 0 . 4 5 3}$ & $\mathbf{- 0 . 7 5 6}$ & $\mathbf{- 0 . 8 6 5}$ & $\mathbf{- 0 . 7 3 8}$ & $\mathbf{- 0 . 4 0 9}$ \\
& Kendall & $\mathbf{0 . 2 5 6}$ & -0.022 & $\mathbf{- 0 . 3 0 6}$ & $\mathbf{- 0 . 5 4 0}$ & $\mathbf{- 0 . 6 6 4}$ & $\mathbf{- 0 . 5 2 2}$ & $\mathbf{- 0 . 2 6 3}$ \\
SST_NAO & Spearman & $\mathbf{0 . 4 2 3}$ & -0.008 & $\mathbf{- 0 . 4 4 5}$ & $\mathbf{- 0 . 7 5 2}$ & $\mathbf{- 0 . 8 5 5}$ & $\mathbf{- 0 . 7 3 7}$ & $\mathbf{- 0 . 4 2 3}$ \\
& Kendall & $\mathbf{0 . 2 6 7}$ & -0.003 & $\mathbf{- 0 . 2 9 1}$ & $\mathbf{- 0 . 5 3 6}$ & $\mathbf{- 0 . 6 4 6}$ & $\mathbf{- 0 . 5 2}$ & $\mathbf{- 0 . 2 6 9}$ \\
& & & & & & & &
\end{tabular}

precipitation is a winter time phenomenon [stronger intensity is coupled to a precipitation decrease over most of the continent (Gong and Ho 2002)], a diminishing intensity over the spring that corresponds to increasing precipitation, low pressure over the summer that corresponds to maximum precipitation, and then an increasing intensity over the fall that corresponds to decreasing precipitation point toward a connection over the entire year.

The stepwise linear regression model revealed the following combination of input variables as being capable of explaining most of the variance of the Shaliguilanke subcatchment precipitation $\left(r^{2}=0.87\right)$ : SHI, WCI, and SSTs of the Arctic Ocean (SST_ArctOc) and the North Atlantic Ocean (SST_NAtlOc). More details about the relation between the SHI and precipitation are provided above. The relationship between the latter three indices and precipitation is briefly described in the following.

WCI $\mathrm{Wu}$ et al. (2012) presented the WCI, which represents the strength of the westerly circulation. The significance of the westerly circulation for precipitation in the study area is also described in several other studies such as in Bothe et al. (2012) and Li et al. (2008).

SST_ArctOc and SST_NAtlOc The Arctic Ocean and the North Atlantic Ocean oscillations were identified as important sources of water vapour for Northwestern China in Dai et al. (2007) and Li et al. (2008). Higher (lower) than normal SSTs will enhance (reduce) the moisture supply.

The source of information presented in Table 2 is calculation based on NCEP/NCAR reanalysis (data provided by the NOAA/OAR/ESRL PSD, Boulder, Colorado, USA, from http://www.esrl.noaa.gov/psd).

\section{Concluding remarks}

The flow conditions of the upper River Aksu, whose basin is shared by Kyrgyzstan and China (Xinjiang Uyghur Autonomous Region), are highly influenced by climate variability. This is of considerable importance, since the River Aksu provides about $75 \%$ of the water for the River Tarim, in the arid to hyper-arid environment, where scarce water resources serve a growing population and heavy vulnerable agroecosystems. Generally, as glaciers retreat due to warming, river flow could increase in the short term but decline once the glaciers continue shrinking and, ultimately, disappear.

Changes in climatic variables (temperature, precipitation) and streamflow were found by multiple trend analysis with different start and end years. The links between climatic variables and river flow were analysed using several approaches at various temporal scales-correlations using daily and monthly data (without and with delay) and climate elasticity of streamflow.

The present paper contributes to an improved understanding of runoff generation processes in the subcatchments of the River Aksu. Besides temperature increase in the region, there have been increasing trends in the discharge of the River Aksu. The influence of variations in summer precipitation and temperature on changes in streamflow was investigated using a range of statistical tools at different temporal scales. While discharge variations in the highly glacierized subcatchment of the Xiehela station are strongly influenced by changes in temperature at temporal scales from daily to annual, in the subcatchment Shaliguilanke with a smaller glacier cover, changes in precipitation play a greater role at the seasonal and annual time scales. On a daily time scale, discharge in both subcatchments shows a strong correlation with temperature while there is no correlation with precipitation. A clear link between daily temperature and daily river discharge dynamics in summer was identified for the Xiehela subcatchment, with a 1-3 day time lag (temperature peaks preceding discharge peaks). However, although the correlation between daily temperature and daily river discharge in the Xiehela station was generally found to be high for summer periods, it breaks over short periods in the end of 
summer or beginning of autumn. This behaviour of the flow generation mechanism can be explained via GLOFs of the Lake Merzbacher.

The importance of precipitation for runoff generation became most apparent in the Shaliguilanke subcatchment. Using four different climate indices, it was possible to explain $87 \%$ of the variance of the Shaliguilanke subcatchment precipitation 4 months in advance. This is a promising result for a potential applicability of seasonal forecasting.

Acknowledgments The research reported in this paper has been carried out within the SuMaRiO project (Sustainable Management of River Oases along the Tarim River/China), funded by the BMBF (German Ministry for Education and Research)—Funding Measure "Sustainable Land Management", reference number: LLA2-02. Constructive advice of anonymous referees is gratefully acknowledged.

Open Access This article is distributed under the terms of the Creative Commons Attribution License which permits any use, distribution, and reproduction in any medium, provided the original author(s) and the source are credited.

\section{References}

Bolch T (2007) Climate change and glacier retreat in northern Tien Shan (Kazakhstan/Kyrgyzstan) using remote sensing data. Global Planet Change 56:1-12

Bothe O, Fraedrich K, Zhu X (2012) Precipitation climate of Central Asia and the large-scale atmospheric circulation. Theor Appl Climatol. 108:345-354. doi:10.1007/s00704-011-0537-2

Chen YN, Li WH, Xu CC, Hao XM (2007) Effects of climate change on water resources in Tarim River Basin, Northwest China. J Environ Sci. 19:488-493. doi:10.1016/S1001-0742(07)60082-5

Chen Y, Xu C, Hao X, Li W, Chen Y, Zhu C, Ye Z (2009) Fifty-year climate change and its effect on annual runoff in the Tarim River Basin, China. Quat Int 208:53-61

Dai X, Li W, Ma Z, Wang P (2007) Water-vapor source shift of Xinjiang region during the recent twenty years. Prog Nat Sci 17:569-575. doi:10.1080/10020070708541037

Dikikh AN (1993) Lednikovyi stok rek Tyan-Shanya i ego rol' v formirovanii obshego stoka (Glacier runoff in the rivers of Tien Shan and its role in total runoff formation). Materialy Glaciologicheskikh Issledovanii 77:41-50 (in Russian)

Fan YT, Chen YN, Li WH, Wang HJ, Li XG (2011) Impacts of temperature and precipitation on runoff in the Tarim River during the past 50 years. J Arid Land 3(3):220-230

Feike T, Mamitimin Y,Li L, Abdusalih N, Doluschitz R (2014) Development of agricultural land and water use and its driving forces in the Aksu-Tarim Basin, P. R. China. Environ Earth Sci (submitted)

Fu G, Charles SP, Chiew FHS (2007) A two-parameter climate elasticity of streamflow index to assess climate change effects on annual streamflow. Water Resour Res 43:W11419. doi:10.1029/ 2007WR005890

Giese E, Moßig I (2004) Klimawandel in Zentralasien, ZEU Discussion Papers 17, p 70, Giessen

Glazirin G (2010) A century of investigations on outbursts of the icedammed Lake Merzbacher (central Tien Shan). Austrian J Earth Sci 103(2):171-179
Gong DY, Ho CH (2002) The Siberian high and climate change over middle to high latitude Asia. Theor Appl Climatol. 72:1-9. doi: $10.1007 / \mathrm{s} 007040200018$

Gong DY, Wang SW, Zhu JH (2001) East Asian winter monsoon and Arctic oscillation. Geophys Res Lett 28:2073-2076. doi:10. 1029/2000GL012311

Goswami BN, Krishnamurthy B, Annamalai H (1999) A broad-scale circulation index for interannual variability of the Indian summer monsoon. Q J R Meteorol Soc. 125:611-633. doi:10.1002/qj. 49712555412

Harris I, Jones PD, Osborn TJ, Lister DH (2013) Updated highresolution grids of monthly climatic observations-the CRU TS3.10 Dataset. Int J Climatol. doi:10.1002/joc.3711

Huang Sh, Krysanova V, Zhai J, Su B (2014) Impact of intensive irrigation activities on river discharge under agricultural scenarios in the semi-arid Aksu River basin, northwest China. Water Resour Manag (in review)

Huang G, Liu Y, Huang R (2011) The interannual variability of summer rainfall in the arid and semiarid regions of Northern China and its association with the Northern Hemisphere circumglobal teleconnection. Adv Atmos Sci 28:257-268. doi:10.1007/s00376-010-9225-x

Kendall MG (1975) Rank correlation methods. Charles Griffin Book Series. Oxford University Press, Oxford, p 272

Kriegel D, Mayer C, Hagg W, Vorogushyn S, Duethmann D, Gafurov A, Farinotti D (2013) Changes in glaciation, climate and runoff over the past four decades in the Naryn basin, Central Asia. Global Planet Change 110:51-61. doi:10.1016/j.gloplacha.2013. 05.014

Krysanova V, Wortmann M, Bolch T, Merz B, Duethmann D, Walter J, Huang Sh, Jiang T, Su B, Liu Sh, Kundzewicz ZW (2014) Analysis of current trends in climate parameters, river discharge, glaciers and land cover in the Aksu River basin (Central Asia). Hydrol Sci J (in review)

Li B, Zhu A, Zhang Y, Pei T, Qin C, Zhou C (2006) Glacier change over the past four decades in the middle Chinese Tien Shan. J Glaciol 52:425-432

Li HJ, Jiang ZH, Wei WS (2007) Drought and flood of Tarim River basin in recent 40 years. Scientia Geographica Sinica 27:801-807 (in Chinese, English abstract)

Li WL, Wang KL, Fu SM, Jiang H (2008) The Interrelationship between Regional Westerly Index and the Water Vapor Budget in Northwest China. J Glaciol Geocryol. 30:28-34 (in Chinese, English abstract)

Li ZQ, Wang WB, Zhang MJ, Wang FT, Li HL (2010) Observed changes in streamflow at the headwaters of the Urumqi River, eastern Tianshan, central Asia. Hydrol Process 24(2):217-224

Ling $\mathrm{H}, \mathrm{Xu} \mathrm{H}, \mathrm{Fu} \mathrm{J}$ (2013) High- and low-flow variation in annual runoff and their response to climate change in the headstreams of the Tarim River, Xinjiang, China. Hydrol Process 27:975-988. doi:10.1002/hyp.9274

Mannig B, Müller M, Starke E, Merkenschlager C, Mao W, Zhi X, Podzun R, Jacob D, Päth H (2013) Dynamical downscaling of climate change in Central Asia. Global Planet Change 110:26-39. doi:10.1016/j.gloplacha.2013.05.008

Osmonov A, Bolch T, Xi Ch, Kurban A, Guo W (2013) Glacier characteristics and changes in the Sary-Jaz River Basin (Central Tien Shan, Kyrgyzstan)-1990-2010. Remote Sens Lett 4(8):725-734

Risbey JS, Entekhabi D (1996) Observed Sacramento Basin streamflow response to precipitation and temperature changes and its relevance to climate impact studies. J Hydrol 184:209-223

Schaake JC (1990) From climate to flow. In: Waggoner PE (ed) Climate change and U.S. water resources, chap. 8. Wiley, New York, pp 177-206 
Sen PK (1968) Estimates of the regression coefficient based in Kendall's tau. J Am Stat Assoc 63:1379-1389

Tao H, Gemmer M, Bai Y, Su B, Mao W (2010) Trends of streamflow in the Tarim River Basin during the past 50 years: human impact or climate change? J Hydrol 400:1-9. doi:10.1016/j.hydrol.2011. 01.016

Unger-Shayesteh K, Vorogushyn S, Farinotti D, Gafurov A, Düthmann D, Mandychev A, Merz B (2013) What do we know about past changes in the water cycle of Central Asian headwaters? A review. Global Planetary Change 110:4-25. doi:10.1016/j. gloplacha.2013.02.004

Wang Y (ed) (2006) Local records of the Akesu River basin. Fangzhi Publisher, Beijing, p 719

Wang B, Wu Z, Li J, Liu J, Chang CP, Ding Y, Wu G (2008) How to measure the strength of the East Asian summer monsoon. J Clim 21:4449-4463

Wang GY, Shen YP, Zhang JG et al (2010) The effects of human activities on oasis climate and hydrologic environment in the Aksu River Basin, Xinjiang, China. Environ Earth Sci 59(8):1759-1769. doi:10.1007/s12665-009-0158-6

Webster PJ, Yang S (1992) Monsoon and ENSO: selectively interactive systems. Q J R Meteorol Soc 118:877-926. doi:10. 1002/qj.49711850705

Weedon GP, Gomes S, Viterbo P, Shuttleworth WJ, Blyth E, Österle H, Adam JC, Bellouin N, Boucher O, Best M (2011) Creation of the WATCH forcing data and its use to assess global and regional reference crop evaporation over land during the twentieth century. J Hydromet 12:823-848

Wortmann M, Krysanova V, Kundzewicz ZW, Su B, Li X (2014) Assessing the influence of the Merzbacher Lake outburst floods on discharge using the hydrological model SWIM in the Aksu headwaters, Kyrgyzstan/NW China. Hydrol Process (accepted)
Wu J (2012) Evaluation of the water resource reproducible ability on Tarim River Basin in south of Xinjiang, northwest China. Environ Earth Sci 66(7):1731-1737. doi:10.1007/s12665-0111396-y

Wu YP, Shen YP, Li BL (2012) Possible physical mechanism of water vapor transport over Tarim River Basin. Ecol Complex. 9:63-70. doi:10.1016/j.ecocom.2011.12.002

Xie Z, Guan D, Zhang S, Ding Y, Shiyin L (2013) Index for hazard of Glacier Lake Outburst flood of Lake Merzbacher by satellitebased monitoring of lake area and ice cover. Global Planet Change 107:229-237

Xu C, Chen Y, Hamid Y, Tashpolat T, Chen Y, Ge H, Li W (2009a) Long-term change of seasonal snow cover and its effects on river runoff in the Tarim River basin, northwestern China. Hydrol Process 23:2045-2055. doi:10.1002/hyp.7334

$\mathrm{Xu} \mathrm{H}$, Zhou B, Song Y (2009b) Impacts of climate change on headstreams runoff in the Tarim River Basin. Hydrol Res 42(1):20-29

Xu ZX, Liu ZF, Fu GB, Chen YN (2010) Trends of major hydroclimatic variables in the Tarim River basin during the past 50 years. J Arid Environ 74:256-267

Xu JH, Chen YN, Feng Lu, Li WH, Zhang LJ, Hong YL (2011) The Nonlinear trend of runoff and its response to climate change in the Aksu River, Western China. Int J Climatol 31:687-695

Zhang H, Ouyang Z, Zheng H, Wang X (2009) Recent climate trends on the Northern slopes of the Tianshan Mountains, Xinjiang, China. J Mt Sci 6:255-265

Zhao QD, Ye BS, Ding YJ et al (2013) Coupling a glacier melt model to the Variable Infiltration Capacity (VIC) model for hydrological modeling in north-western China. Environ Earth Sci 68(1):87-101. doi:10.1007/s12665-012-1718-8 